\title{
PEMANFAATAN EKSTRAK DAUN JAMBU BIJI (Psidium guazava) SEBAGAI GEL FACIAL WASH ANTIJERAWAT
}

\author{
${ }^{1}$ Neni Sri Gunarti \\ ${ }^{1}$ Prodi Farmasi Fakultas Teknologi dan Ilmu Komputer Universitas Buana Perjuangan \\ Karawang (neni.gunarti@ubpkarawang.ac.id)
}

\begin{abstract}
ABSTRAK
Daun Jambu Biji memiliki aktivitas antibakteri terhadap Propionibacterium acnes, Staphylococcus aereus dan Staphylococcus epidermis yang merupakan bakteri penyebab jerawat. Maka dilakukan penelitian formulasi sediaan gel facial wash dari ekstrak daun jambu biji. Formulasi menggunakan bahan aktif ekstrak etanol daun jambu biji dengan konsentrasi 2,5\%, 5\% dan 7,5\%. Bahan tambahan yang digunakan adalah gliserin, metilparaben, propilparaben, carbopol, trietanolamin, natrium lauril sulfat dan aquadest. Hasil formulasi dilakukan uji kualitas sediaan berupa organoleptik, $\mathrm{pH}$, viskositas, daya sebar, tingkat busa dan aktivitas antibakteri terhadap Propionibacterium acnes. Hasil penelitian menunjukkan bahwa formula dengan ekstrak jambu biji 2,5\% memiliki kualitas sediaan dan aktivitas antijerawat paling baik.
\end{abstract}

Kata Kunci : Daun Jambu Biji, Propionobacterium acnes, Gel facial wash

\section{PENDAHULUAN}

Kosmetik adalah sediaan atau paduan bahan yang siap digunakan pada bagian luar badan (epidermis, rambut, kuku, bibir, dan organ kelamin bagian luar badan), gigi dan rongga mulut untuk membersihkan, menambahkan daya tarik, mengubah penampakan, melindungi agar tetap dalam keadaan baik, memperbaiki bau badan tetapi tidak dimaksudkan untuk mengobati atau menyembuhkan suatu penyakit (Tranggono dan Latifa, 2007).

Acne atau bisa disebut jerawat, merupakan salah satu masalah yang banyak dialami oleh masyarakat, terutama yang menyerang bagian wajah. Etiologi Acne sampai saat ini termasuk multifactorial namun pravelensinya meningkat seiring dengan diantaranya berbagai faktor, diantaranya polusi udara, pola makan tinggi lemak, dan meningkatnya tingkat stress di kalangan masyarakat (Krowchuk dan Anthony, 2008). Propionibacterium acnes merupakan bakteri komensial pada kulit manusia yang beperan menghalangi kolonisasi bakteri-bakteri pathogen pada kulit yang sehat. Bakteri ini tergolong dalam bakteri Gram positif, bersifat anaerob, tidak berspora, berbentuk batang pleomorfik yang menghasilkan produk akhir 
fermentasi berupa asam propionat. P. acnes merupakan organisme predominan didalam folikel pilosebasea.

Pertumbuhan bakteri Propionibacterium acnes dapat di hambat dengan menggunakan bahan sintetis dan bahan alam, salah satu bahan alam yang di ketahui mengandung antibakteri adalah Daun Jambu Biji. Daun Jambu Biji di gunakan sebagai Antijerawat karena memiliki aktivitas antibakteri terhadap Propionibacterium acnes, Staphylococcus aereus dan Staphylococcus epidermis (Qa' at al, 2005). Telah dilaporkan bahwa aktivitas antibakteri pada ekstrak daun Jambu Biji dipengauhi karena adanya kandungan tanin, triterpenoid, dan glikosida flavonoid yang terdapat pada daunnya (Yulianti, 2015). Gel adalah sistem semipadat di mana fase cairnya dibentuk dalam suatu matriks polimer tiga dimensi (terdiri dari gom alam atau gom sintetis) yang tingkat ikatan silang fisik (atau kadang-kadang kimia) nya tinggi.

\section{METODE PENELITIAN}

Metode yang digunakan dalam penelitian ini adalah metode experiment dengan menggunakan sampel ekstrak daun jambu biji.

\section{III.1 Alat dan Bahan}

Alat yang digunakan maserator, pisau, waterbath, blender, evaporator, timbangan analitik, ayakan mesh 40, cawan porselen $100 \mathrm{ml}$, botol kaca, plastic wrap, alumunium foil, beaker glass $50 \mathrm{ml}$, gelas ukur $10 \mathrm{ml} ; 50 \mathrm{ml} ; 100 \mathrm{ml}$,batang pengaduk, kertas saring, kapas steril, dan spatula, kertas saring, kaca arloji, timbangan analitik, spatula, beaker glass $250 \mathrm{ml}$, kompor listrik, batang pengaduk, mortir, stemper, sudip, kawat kasa, botol semprot. Bahan yang digunakan etanol 96\%, Daun Jambu Biji, Gliserin, Methylparaben, Propylparaben, Na- Lauril sulfat, Carbopol, Trietanolamin, Aquadest.

\section{III.2 Prosedur Percobaan}

Pada percobaan ini dilakukan beberapa langkah percobaan sebagai berikut :

\section{Pembuatan Ekstrak Daun Jambu Biji}

Pembuatan ekstrak daun Jambu Biji dilakukan dengan cara ekstrasi cara dingin yaitu Maserasi, yaitu daun Jambu Biji yang sudah di panen dan disortasi dibersihkan dengan air mengalir, lalu ditiriskan. Setelah ditiriskan daun Jambu Biji dikeringkan di bawah sinar matahari, setelah kering simplisia diserbukkan dengan menggunakan blender dan di timbang lalu di ekstraksi dengan menggunakan pelarut etanol 96\%. Selanjutnya filtrat dikumpulkan dan diuapkan menggunakan rotary evaporator pada suhu dibawah 50oC sampai volumenya 
menjadi 1/4 dari volume awal, dan dilanjutkan dengan pemekatan ekstrak yang dilakukan dengan menggunakan waterbath dengan suhu $60 \mathrm{oC}$ sampai menjadi ekstrak pekat daun Jambu Biji.

\section{Pembuatan Sediaan gel Facial Wash}

Pembuatan Gel facial wash ekstrak daun Jambu Biji dilakukan dengan mencampurkan Carbopol dengan aquadest panas pada mortar yang sudah dipanaskan lalu aduk homogen hingga mengembang. Larutkan methylparaben dan propylparaben dengan aquadest di mortar tambahka Na-Lauril Sulfat lalu aduk hingga homogeny tambahka gliseri. Setelah itu masukan ekstrak daun Jambu Biji lalu aduk hingga homogeny masuka basis ge sedikit demi sedikit sambil diaduk higga tercampur semua dan yang terakhir penambahan TEA lalu aduk ad homogen.

\begin{tabular}{|l|l|l|l|}
\hline Nama Zat & F1 & F2 & F3 \\
\hline Ekstrak daun Jambu Biji (\%) & 2,5 & 5 & 7,5 \\
\hline Gliserin (\%) & 15 & 15 & 15 \\
\hline Metilparaben (\%) & 0,18 & 0,18 & 0,18 \\
\hline Propilparaben (\%) & 0,02 & 0,02 & 0,02 \\
\hline Carbopol (\%) & 1 & 1 & 1 \\
\hline Na-Lauril Sulfat (\%) & 2 & 2 & 2 \\
\hline Trietanolamin (\%) & 2 & 2 & 2 \\
\hline Aquadest ad (gram) & 50 & 50 & 50 \\
\hline
\end{tabular}

\section{Evaluasi Gel Facial Wash}

Evaluasi gel facial wash meliputi uji organoleptis, viskositas, tingkat busa, $\mathrm{pH}$, daya sebar dan uji aktivitas antibakteri terhadap bakteri Propionibacterium acnes.

\section{Uji efektivitas antibakteri}

Uji efektivitas antibakteri dari gel facial wash dilakukan dengan metode disc diffusion. Kertas cakram direndam dalam gel F1, F2, F3, control negatif dan control positif selama 3 menit diletakkan pada permukaan media Triptic Soy Agar (TSA) yang telah diinokulasikan bakteri Psidium guajava L. pengujian dilakukan 3 kali pengulangan dan diukur zona hambat menggunakan jangka sorong.

\section{PEMBAHASAN}


Hasil evaluasi organoleptik untuk formula yang dibuat berwarna hijau dengan bau khas jambu biji. Konsentrasi ekstrak yang digunakan mempengaruhi konsistensi gel yang dibuat, semakin banyak ekstrak yang digunakan semakin kental sediaan gel dan warna yang dihasilkan semakin pekat. Pada uji viskositas gel facial wash ditetapkan viskositas sebesar 500 - 20.000 cps. Dari tabel pengamatan (tabel 2), ketiga formula memenuhi persyaratan viskositas gel. Hasil evaluasi daya sebar ketiga formula (tabel 2) memenuhi persyaratan yang ditetapkan yaitu 5-7 cm. daya sebar berbanding terbalik dengan viskositas. Semakin tinggi viskositas, daya sebar yang didapat semakin kecil (Eugresya et al, 2017). Untuk hasil evaluasi pH ketiga formula, syarat yang ditetapkan adalah 6-8 dari hasil didapat nilai rentang $\mathrm{pH}$ seperti yang tertera pada tabel 1.

Tabel 1. Evaluasi sediaan

\begin{tabular}{lllll} 
Evaluasi & Persyaratan & \multicolumn{2}{l}{ Hasil pengamatan } \\
\cline { 3 - 5 } & & F1 & F2 & F3 \\
\hline Bentuk & Gel & Gel & Gel & Gel \\
\hline Warna & Hijau & Hijau & Hijau & Hijau \\
\hline Bau & Jambu biji & Jambu biji & Jambu biji & Jambu biji \\
\hline Tingkat busa & 3-10ml/10 & 6,37 & 4,67 & 5,67 \\
& menit & & & \\
\hline Daya sebar (cm) & $5-7$ & $6,3 \pm 0,43$ & $6,28 \pm 0,30$ & $6,56 \pm 0,14$ \\
\hline Viskositas (cps) & $500-20.000$ & $4683,67 \pm 150,44$ & $1991,67 \pm 74,144$ & $5621 \pm 2812,91$ \\
\hline pH & $6-8$ & $7,37 \pm 0,04$ & $7,69 \pm 0,02$ & $7,43 \pm 0,02$
\end{tabular}

Pengujian aktivitas antibakteri gel ekstrak daun jambu biji bertujuan untuk mengetahui apakah ekstrak facial wash daun jambu biji memiliki aktivitas antijerawat terhadap bakteri Propionibacterium acnes atau tidak. Dari hasil pengamatan, menunjukkan bahwa gel facial wash ekstrak daun jambu biji memiliki aktivitas antibakteri seperti yang tertera pada tabel 3 .

Tabel 2. Kategori penghambatan

\begin{tabular}{ll}
\multicolumn{1}{c}{ Diameter $(\mathbf{m m})$} & Respon hambatan pertumbuhan \\
\hline $0-3$ & Lemah \\
\hline $3-6$ & Sedang \\
\hline$>6$ & Kuat
\end{tabular}


Dari hasil yang didapat pada tabel 3, zona hambat yang terbentuk dapat dikategorikan memiliki aktivitas antibakteri yang kuat karena memiliki nilai $\geq 6 \mathrm{~mm}$ (tabel 2). Yang dapat diartikan bahwa, dengan konsentrasi minimal saja sudah dapat menghambat pertumbuhan bakteri. Dan didapat hasil bahwa ekstrak daun jambu biji memiliki aktivitas antijerawat yang kuat terhadap bakteri Propionibacterium acnes.

Tabel 3. Hasil Evaluasi

\begin{tabular}{lll} 
Bakteri Uji & Sampel & Diameter rata-rata Zona Hambat $(\mathbf{m m})$ \\
\hline P.acnes & F1 & $16,25 \pm 1,068$ \\
\cline { 2 - 3 } & F2 & $12,24 \pm 1,264$ \\
\cline { 2 - 3 } & F3 & $13,46 \pm 2,688$ \\
\cline { 2 - 2 } & K (-) & 0
\end{tabular}

\section{PENUTUP}

Ekstrak daun jambu Biji (Psidium guazava) dapat dimanfaatkan sebagai sediaan gel facial wash antijerawat. Formula F1, F2, dan F3 memberikan hasil sediaan gel yang baik dan memenuhi persyaratan. Dari ketiga formula, F1 yang memiliki aktivitas penghambatan terhadap bakteri $\mathrm{P}$. acne terbaik yaitu $13,46 \pm 2,688 \mathrm{~mm}$ yang menunjukkan respon hambatan kuat .

\section{DAFTAR PUSTAKA}

Ajizah A. 2004. Sensitivitas Salmonella typhimurium terhadap ekstrak daun Psidium guajava L. Bioscientiae Vol.1 No.1.

Akiyama, H., Fujii K., Yamasaki O., Oono T., Iwatsuki T.,. 2001. Antibacterial action of several tannins againt Staphylococcus aureus. Journal of Antimicrobial Chemotheraphy Vol. 48.

Anthony J. Mancini. 2008. Incidence, Prevalence, and Pathophysiology of Acne volume 8 no.4 John Hopkins Advanced Studies in Medicine.

Biswas B , Rogers K, McLaughlin F, Daniels D, Yadav A. 2013. Antimicrobial activities of leaf extracts of guava (Psidium guajava $L$ ) on two gram-negative and gram-positive bacteria. International Jurnal of Microbiology. 
Eugresya, Gabriela, ChristinaAvanti, Stella Agustina Uly. 2017. Pengembangan Formula dan Uji Stabilitas Fisik-pH Sediaan Gel Facial Wash yang Mengandung Ekstrak Etanol Kulit Kayu Kesambi. Surabaya : Fakultas Farmasi Universitas Surabaya

Fratiwi Yolanda, 2015. The Potentials Of Guava Leaf (Psidium guajava L.) For Diarrhea Faculty of Medicine, Lampung University.

Krowchuk DP. 2005. Managing adolescent acne: a guide for pediatricians. Pediatr Rev.

Lachman, L., Lieberman, H. A., and Kanig, J.L., 1994, Teori dan Praktik Industri farmasi, diterjemahkan oleh Suyatmi, S., Jakarta, UI Press.

Nety Nurazizah, 2008. Isolasi dan Identifikasi Jamur Endofit Dari Daun Jambu Biji (Psidium Guajava L.) sebagai Anti bakteri Dari Bakteri E.Coli dan Staphylococus Aureus, UIN Malang, Malang.

Ojewole JA. 2006. Antiinflammatory and analgesic effects of Psidium guajava L. Linn. (Myrtaceae) leaf aqueous extract in rats and mice. Methods and findings in experimental and clinical pharmacology.

Oktabimasakti, Sri Luliana, Wintara Taurina. Efektivitas Antibakteri Gel Antiseptik Ekstrak Metanol Kulit Batang Tanjung (Mimusops elengi L.) Terhadap Bakteri Eschericia coli dan Staphylococcus aureus. Pontianak : Universitas Tanjungpura

Oktavia Nikken Rima. 2014. Efektivitas Beberapa Sabun Pembersih Wajah Antiacne terhadap Pertumbuhan Bakteri Propionibacterium Acnes. Universitas Islam Negeri Syarif Hidayatullah. Jakarta

Prawira MY, Sarwiyono, P Surjowardojo. Daya Hambat Dekok Daun Kersen (Muntingia calabura .,) Terhadap Pertumbuhan Bakteri Staphlococcus aureus Penyebab Penyakit Mastitis. Malang : Universitas Brawijaya

Qa'dan F., Thewani A.J., Ali D.A., Afifi R., Elkhawad A., Matalka K.Z. 2005. The antimicrobial activities of Psidium guajava and Juglans regia leaf extract to acnedeveloping organism, Am J chin Med.

Septia Anggraini, 2010. Optimasi Formula Fast Disintegrating Tablet Ekstrak Daun JambuBiji (Psidium Guajava L.) Dengan Bahan Penghancur Sodium Starch Glycolate Dan BahanPengisi Manitol, Universitas Muhammadiyah Surakarta, Surakarta.

Tranggono dan Latifah. 2007. Buku Pegangan Ilmu Pengetahuan Kosmetik, Editor: Jhosita Djadjadisastra. Jakarta: Penerbit Pustaka Utama.

Yulianti Rika, 2015. Formulasi Krim Antijerawat Kombinasi Ekstrak Daun Sirsak (Annona muricata L.,) dan Daun Jambu Biji (Psidium guajava L., ). Jurnal Bakti Tunas Husada. STIkes BTH Tasikmalaya, Tasikmalaya. 
Yulinar Rochmasari, 2011. Studi Isolasi Dan Penentuan Struktur Molekul Senyawa Kimia Dalam Fraksi Netral Daun Jambu Biji Australia (Psidium Guajava L.), Universitas Indonesia, Depok,. 